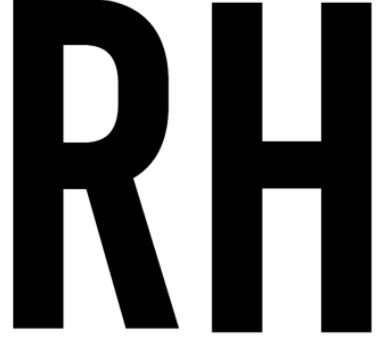

RADICALHOUSINGJOURNAL

\title{
Escaping the parasite of
} the student flat: Reflections on an experiment in co-operative housing

\author{
Hamish Kallin \\ University of Edinburgh and \\ Mike Shaw \\ Edinburgh Student Housing Co-operative Ltd.
}

Hamish Kallin is a Lecturer in Human Geography at the

University of Edinburgh.

Mike Shaw is a co-founder and member of the Edinburgh Student Housing Co-operative Ltd. Contact: h.kallin@ed.ac.uk

\begin{abstract}
Students are increasingly cast as active agents who exacerbate the housing crisis in British cities. In Edinburgh (Scotland), rising student numbers has led to an acute tension, with the wider population concerned over contested claims to space. As a transient population who are forced to pay high rents, students are associated with new-build developments that market a "luxury" lifestyle in gated complexes that are necessarily exclusive. Contrary to this, we show how students are themselves victims of financialization through both the classroom and their homes. But they do not have to accept this role. Through the example of the Edinburgh Student Housing Co-operative, we explore one bold attempt to break out of this conjecture and escape the parasite of the student flat.
\end{abstract}

\section{Keywords}

student housing, co-operatives, studentification, Edinburgh

Students have the unenviable position of being cast both as cause and victim of the housing crisis. In Edinburgh (Scotland), they are perceived as a cause because they make up a sizeable and growing proportion of the population (almost $12 \%$ of 507,000 inhabitants), fuelling investment in purpose-built student accommodation (PBSA), squeezing out alternative land uses. The link between studentification and gentrification is nothing new (Smith, 2005), but the intensified marketization of universities since the financial crisis has 
exacerbated this connection. Simultaneously, students are victims because they are increasingly indebted and exploited through their housing. Across the UK, PBSA rents in the private sector rose by over 18\% between 2012 and 2015 (NUS/UNIPOL, 2015). In Edinburgh, the average cost of a room in one of these blocks is now $£ 674$ a month and rising above inflation (EUSA, 2016). Rather than accept this dual status, we want to suggest that students are not a cause of this crisis, and they do not need to be its victims. First, we show how the problem is rooted in wider processes, not students themselves. Second, we introduce the example of one bold attempt to break out of this conjecture through the Edinburgh Student Housing Co-operative.

The pressures of studentification in Edinburgh are acute, as several ongoing campaigns against new-build student housing demonstrate ("Save Leith Walk" being the most vocal right now). Rents in the private sector have risen by $40 \%$ over the last seven years. House prices have risen $15 \%$ in the last year alone, and almost 24,000 families are waiting on the social housing list. Airbnb listings doubled last year, more than half of which were entire properties (Rae, 2017). The perceived role of students in this process has accelerated over recent years as student housing increasingly adopts the architectural form of "luxury", and often gated, developments (Chatterton, 2010). The marketization of higher education in the UK has been ongoing for decades (McGettigan, 2011), and universities increasingly look to overcome the gap left by cuts to funding through both fees and rent. These have the benefit of being closely connected: attract more students, and you make more money from both revenue streams. Along these lines, the University of Edinburgh has committed to sustained "growth", focussing on overseas masters students (who pay the highest fees).

Investment in PBSA was worth $£ 4.5$ billion in 2016 , with rises of $17 \%$ predicted (Savills, 2017). Demand is set through institutional targets, underpinned by government-backed debt. In England, the total amount lent out through "maintenance loans" (to cover the cost of living, i.e. not tuition fees) has almost doubled in the last decade to just over $£, 5$ billion annually (House of Commons Library, 2018). In Scotland, it has more than doubled to $f, 547$ million in the last five years (Student Loans Company, 2018). In other words, there is a growing pile of government-backed debt underpinning the profitability of the sector. Average student rents in Scotland are now $112 \%$ of the maximum maintenance loan (NUS/UNIPOL, 2015). In this way, government money subsidizes private developers on a massive scale under the guise of an egalitarian policy designed to enable poorer students to attend university, saddling those students with debt in the process.

Private developers invest in student housing because, under specific historic conditions, students are currently a prime vehicle for the extraction of rent. In Edinburgh, this embodied form of potential profit is matched only by the tourist. These twin figures risk becoming the folk devils of contemporary anti-gentrification activism. But the problem is not students themselves who, like all of us, simply need somewhere decent to live. The problem, as we have hinted at, lies in far broader processes of financialization-both of real estate and of degrees - and the neoliberalization of the academy. This gives rise to an especially parasitic form of rentier economy, for students are a uniquely transient demographic, arriving en masse 
at the same time. Those without local connections become a kind of "captive audience", for they have nowhere else to go...

The austerity agenda compels universities to chase rent as a source of income, but it also spawned a protest movement of unexpected scale and vitality. It is easy to dismiss the wave of occupations and protests that swept across British universities in the winter of 2010 as failures (fees rose; funding was cut), but in terms of individuals, networks, and ideals, there is a direct link between that collective experience and many subsequent campaigns. In London, we have seen this resentment explode in a series of rent strikes. And in Edinburgh, there is one success story we would like to share.

With 106 beds in 24 shared flats, the Edinburgh Student Housing Co-operative (ESHC) is the largest student-run housing co-operative outside North America, and the only one in the world to operate at this scale on the model of direct democracy, explicitly influenced by the ideals of anarchism. The Co-op opened in 2014, spearheaded by a small group of determined students. Without finance, experience, or a building, progress seemed highly unlikely. Through the support of the local authority and Castle Rock Edinvar Housing Association (CRE), a "surplus" block of 1990s student flats was secured on a five-year lease with right for the Co-op to buy the property at any time. CRE agreed to have the lease and legal fees paid in arrears, providing crucial time to collect the first few months' rent. As such, ESHC received the keys having parted with only $£, 65$ cash (Shaw, 2015; Shaw and Farmelo, 2017).

ESHC has a horizontal structure with no centralized committee of management. From gardeners to bank signatories, every member shares a position of responsibility. The transitory nature of students requires the Co-op to practice knowledge sharing, member education, and training. This is a challenge, but can reduce the risk of institutional stagnation. ESHC is far more than a housing provider, though its additional benefits are difficult to quantify: residents can gain experience in everything from choosing ovens to constructing floors, as well as juggling the ongoing challenges of collective living. It remains by far the cheapest student housing provider in the city. All income is derived from rent, and all profit is spent on running costs and improvements. ESHC is flourishing, with long waiting lists and ambitious plans for expansion. As part of the newly founded UK-wide federation Student Co-operative Homes, ESHC is actively working to replicate its successes elsewhere.

This does not mean the Co-op is without its challenges. An uneven distribution of labour can mean that some members end up more involved than others. "Horizontalism" as an ideal requires constant vigilance, for social hierarchies are often replicated in anarchist circles (Freeman, 2012). The loudest voices mirror distinctions of gender and class, and this can never be overcome by virtue of a constitution alone (though a good structure helps). Whilst specific groups and spaces exist within the Co-op structure to enable open dialogue and address issues as they occur, the practice of 106 students living together is always a workin-progress.

The Co-op also suffers from the limitation that befalls most radical co-operatives: it remains small in scale (and thus necessarily exclusive) compared to the profusion of privately- 
financed alternatives. It still has to negotiate with a market (in terms of acquiring buildings and securing capital). Rather than dismissing ESHC on this basis, we argue that it is one form among many of collectively owned housing models that have the potential to challenge the status quo (Ward, 1990) and upset the idea that students are passive consumers of unaffordable housing designed increasingly as financialized "machines for studying in".

\section{References}

Chatterton, P. (2010). "The student city: an ongoing story of neoliberalism, gentrification, and commodification", Environment and Planning A, 42(3): 509-514.

Freeman, J. (2012). "The Tyranny of Structurelessness", in Dark Star (Eds.) Quiet Rumours: An Anarcha-Feminist Reader. Edinburgh: AK Press.

House of Commons Library. (2017). Student Loan Statistics. Available at: https://researchbriefings.parliament.uk/ResearchBriefing/Summary/SN01079\#fullrep ort (accessed 27 June 2018).

McGettigan, A. (2011). "New providers: The creation of a market in higher education", Radical Philosophy 167: 2-8.

NUS/UNIPOL. (2015). Accommodation Costs Survey 14/16. Available at: https://www.unipol.org.uk/documents/publications/unipol_nus_accommodationcosts survey2015.aspx (accessed 28 June 2018).

Shaw, M. (2015). "There is an Alternative: setting up the Edinburgh Student Housing Cooperative". Students for Cooperation. Available at: http://www.students.coop/there-is-analternative-setting-up-the-edinburgh-student-housing-co-operative/ (accessed 28 June 2018).

Shaw, M. \& Farmelo, S. (2017). "Resisting the housing crisis", in R. Filar (Ed.) Resist! Against a Precarious Future. London. Lawrence \& Wishart.

Smith, D. (2005). "Studentification: the gentrification factory?", in R. Atkinson and G. Bridge (Eds.) Gentrification in a Global Context: the new urban colonialism. London: Routledge.

Student Loans Company. (2018). Student Loans for Higher Education in Scotland. Available at: https://www.slc.co.uk/media/10028/slcsp042018.pdf (accessed 27 June 2018).

Rae, A. (2017). Analysis of Short of Short-Term Lets Data for Edinburgh. Available at: https://greens.scot/sites/default/files/AnalysisShortTermLetsDataforEdinburgh_Alas dairRae_PDF-FINAL_2.pdf (accessed 26 June 2018).

Savills. (2017). Spotlight: UK Student Housing. Available at: http://pdf.euro.savills.co.uk/uk/spotlight-on/spotlight-uk-student-housing-2017.pdf (accessed 27 June 2018).

Ward, C. (1990). Talking Houses. London, Freedom Press. 